\title{
A Disaggregated and Macro-consistent Social Accounting Matrix for Pakistan
}

\author{
Darío Debowicz • Paul Dorosh • \\ Hamza Syed Haider • Sherman Robinson
}

Received: 27 August 2012 / Accepted: 19 March 2013 / Published online: 22 March 2013 (C) 2013 D. Debowicz et al.; licensee Springer. This is an Open Access article distributed under the terms of the Creative Commons Attribution License (http://creativecommons.org/licenses/by/2.0), which permits unrestricted use, distribution, and reproduction in any medium, provided the original work is properly cited.

\begin{abstract}
This paper provides future researchers of economic structure with a model for building a social accounting matrix (SAM), that is, a unique countrywide database for use in structural analysis, and applies this model to the empirical investigation of the economic structure of Pakistan. Our proposed approach to building SAMs is motivated by an information theoretic approach to estimation that takes a Bayesian view of the efficient use of information: "Use all the information you have, but do not assume any information you do not have." The methodology used to develop this SAM, unlike previous approaches, ensures that it is perfectly consistent with the national accounts. The SAM provides a high degree of detail on the economic structure of the country, with 51 sectors of activity, 27 factors of production, and 18 household groups, allowing the tracing of direct and indirect effects of potential scenarios through production and consumption linkages and the capture of distributional effects. Output multipliers in Pakistan, accounting for supply constraints, range from 1.1 to 1.4 , and shocks to livestock and industry have the largest spillover effects. These shocks lead to income changes that differ significantly across domestic socioeconomic groups, a direct result of the heterogeneity in the generation of income of these groups that our countrywide database captures.
\end{abstract}

Keywords Social accounting matrix $(\mathrm{SAM}) \cdot$ Multiplier analysis $\cdot$ Pakistan Economic structure

\footnotetext{
D. Debowicz $(\varangle) \cdot$ P. Dorosh $\cdot$ H.S. Haider $\cdot$ S. Robinson 2033 K Street NW, Washington DC, USA

e-mail: ddebowicz@cgiar.org

P. Dorosh

e-mail: p.dorosh@cgiar.org

H.S. Haider

e-mail: s.h.haider@cgiar.org

S. Robinson

e-mail: s.robinson@cgiar.org
} 


\section{JEL Classification E160 $\cdot$ E170}

\section{Introduction}

A social accounting matrix (SAM) is an internally consistent single-entry accounting system that documents all the economic transactions within an economy. SAMs support the continuing need to use recent and consistent multisectoral economic data for policy analysis and the development of economy wide models (Robinson et al. 2001). A SAM is an extended set of national accounts that disaggregates the value added in each production activity into payments to various factors such as land, labor, and capital, and disaggregates household incomes and expenditures according to various household types. Mathematically, a SAM is a square matrix in which each account is represented by a row and a column. Each cell shows the payment from the account of its column to the account of its row. Thus, the incomes of an account appear along its row and its expenditures along its column. The underlying principle of double-entry accounting requires that, for each account in the SAM, total revenue (row total) equals total expenditure (column total).

Data typically used to build SAMs include an input-output (IO) matrix of the economy, national accounts, fiscal accounts, trade data, other balance-of-payments information, and surveys providing information on the composition of household income and expenditures. Given its ability to capture interindustry linkages and household income and expenditure composition while being consistent with macroeconomic accounts, a SAM can serve as a unique economic database for structural analysis. However, in order for academics to be able to fruitfully employ a SAM to perform up-to-date structural analysis, the SAM needs to provide rich and current detail on the income and expenditure patterns of the production sectors, production factors, and households of an economy: only a SAM with a rich disaggregation of accounts allows the heterogeneity of the income and expenditure composition among households to be reflected in a significant way and, as a result, allows the distributional effects of changes in the composition of output in the economy to be identified.

This paper provides a model for future researchers looking to build a SAM and applies the model to Pakistan, creating a highly disaggregated and updated SAM. This SAM is then used to describe the structure of the Pakistani economy through multiplier analysis in an attempt to provide a useful reference and resource for academics concerned with the structure of Pakistan's economy.

The Pakistani economy has undergone marked changes during the last decade, which call for an updated countrywide database. In only 10 years, the share of the country's service sector increased from $50.7 \%$ (2000) to $54.6 \%$ (2010); the share of the textile sector in total exports decreased from $64.8 \%$ (2000) to $53.0 \%$ (2010); and the labor force grew significantly, due not so much to the annual population growth rate of around $2 \%$, but more to an impressive increase in the labor participation rate, which though still low by international standards, grew from $28.9 \%$ (2000) to $45.7 \%$ (2010) (State Bank of Pakistan 2010).

Our paper is organized as follows. In Sect. 2, we review past SAMs for Pakistan and highlight their relative strengths and weaknesses in capturing sector, factor, and 
Table 1 Previous SAMs for Pakistan

\begin{tabular}{|c|c|c|}
\hline No. & $\begin{array}{l}\text { Name of researchers or } \\
\text { organization }\end{array}$ & Salient features \\
\hline 1 & $\begin{array}{l}\text { Pakistan Institute of } \\
\text { Development Economics } \\
\text { (1985) }\end{array}$ & Base year: 1979 \\
\hline 2 & $\begin{array}{l}\text { Federal Bureau of Statistics } \\
\text { (1993) }\end{array}$ & $\begin{array}{l}\text { Base year: } 1984 / 1985 \\
\text { Households: } 1\end{array}$ \\
\hline 3 & Siddiqui and Iqbal (1999) & $\begin{array}{l}\text { Base year: 1989/1990 } \\
\text { Sectors (5): agriculture, industry, education, health, other } \\
\text { sectors } \\
\text { Factors (2): labor and capital } \\
\text { Agents: households (8), firms, government, rest of the world }\end{array}$ \\
\hline 4 & Dorosh et al. (2004) (DNN) & $\begin{array}{l}\text { Base year: } 2001 / 2002 \\
\text { Sectors (34): agriculture (12), industry (16), services (6) } \\
\text { Factors: } 27 \\
\text { Agents: households (19), enterprises, government, rest of the } \\
\text { world }\end{array}$ \\
\hline 5 & Waheed and Ezaki (2008) & $\begin{array}{l}\text { Base year: 1999/2000 } \\
\text { Sectors (6): agriculture; mining and quarrying; manufacturing; } \\
\text { electricity, water, and gas; construction; other sectors } \\
\text { Factors (2): labor and capital } \\
\text { Agents: households (1), firms, government, commercial banks, } \\
\text { central bank, rest of the world }\end{array}$ \\
\hline
\end{tabular}

We were unable to obtain access to SAMs Nos. 1 and 2. Source: Authors' literature review

household detail. In Sect. 3, we explain our approach to building a SAM and how we apply the model to Pakistan. Based on the resulting SAM, in Sect. 4 we analyze the structure of the Pakistani economy, and in Sect. 5 we conduct income multiplier analysis to further illuminate the economic structure of the country. Section 6 concludes.

\section{Previous Social Accounting Matrixes for Pakistan}

A limited number of SAMs have been constructed for Pakistan (Table 1). The first represented the Pakistani economy in the year 1979 and was constructed in 1985 by the Pakistan Institute of Development Economics. It was followed by a SAM for the year 1984/1985, created by the Federal Bureau of Statistics (FBS) with collaboration from the Dutch government under the Improvement of National Accounting System project. Because this SAM had a single household group, it was not suitable for analyzing distributional effects across households.

Siddiqui and Iqbal (1999) developed another SAM for 1989/1990, aggregating the IO matrix industry classifications into five activity accounts and disaggregating household income and expenditures into eight household groups, allowing for distributional analysis among households. In 2004, Dorosh et al. (2004) (DNN henceforth) 
produced an additional SAM of Pakistan for the year 2001/2002, which even when relying on the same IO matrix as Siddiqui and Iqbal, allowed for much larger disaggregation, containing 19 household groups and 34 production sectors. The suitability for analyzing the effects of shocks in specific industries on different socioeconomic groups improved significantly with this SAM, as households were disaggregated by province (Sindh, Pakistan, and rest of Pakistan) and the number of commodities was larger than in Siddiqui and Iqbal (1999). The DNN SAM is at present informing the Global Trade and Analysis Project SAM for Pakistan, which has five factors and 57 sectors but a single representative household and is therefore not suitable for distributional analysis among household groups. More recently, and relying on the same IO matrix (still the most recent matrix available for the country), Waheed and Ezaki (2008) provided a bridge between the real and the financial sides of the Pakistani economy, reflecting the growing importance of capital flows and the availability of the associated data, by creating a real/financial SAM for the year 1999/2000. However, in this case, production sectors were aggregated into only six accounts, with no disaggregation into different household groups.

\section{Methodology for Developing the SAM}

In designing the accounts for our SAM, we take as a base the accounts of the SAM developed by DNN, as it is the most disaggregated one created thus far for the country. Starting from this base, we further increase the disaggregation of the SAM accounts and use more updated information in many spheres. While the textile industry was aggregated into a single account in DNN, we disaggregate it into knitwear, garments, and other textiles - all relevant textile activities in Pakistan. We disaggregate cotton into ginning, spinning, and weaving, and chemicals into fertilizers and other chemicals. Reflecting the growth of the service sector in the country, we substantially disaggregate this sector: trade (a single account in DNN) is split into wholesale, retail, and other trade; transport into road, rail, air, water, and other transport; housing into rented and owned; and other private-sector services into education, healthcare, business services, personal services, and other private services. As in DNN, households are disaggregated according to province, among other criteria. Out of the 18 household groups, 12 represent agricultural households. Agricultural households are classified by farm ownership and size (small vs. medium/large), ${ }^{1}$ enabling an indepth analysis of the distributional effects of changes in the agricultural sector and its linkages with other industries. Nonagricultural households are classified as urban or rural. While in DNN these groups are disaggregated into two subgroups (poorest $20 \%$ and rest), we disaggregate them into three subgroups according to per capita expenditure: quintile 1 , quintile 2 , and rest.

Our proposed approach to developing SAMs is motivated by an information theoretic approach to estimation (Judge and Mittelhammer 2012) that takes a Bayesian view of the efficient use of information: "Use all the information you have, but do not

\footnotetext{
${ }^{1}$ Medium/large farm households are defined as those owning 12.5 acres or more of land. Small farm households are those owning less than 12.5 acres of land.
} 
assume any information you do not have." Previous work on SAM estimation using this approach includes Judge and Mittelhammer (2012), Golan et al. (1994, 1996), Robinson et al. (2001), Debowicz (2010), and Zellner (2004).

In this spirit, we have designed a series of major steps that we list in Fig. 1 that lead to an estimated macro-consistent and disaggregated SAM for a countrywide economy. The steps, which are explained in detail below, start from a schematic SAM (Table 2) and, using a variety of data sources and balancing the accounts of the SAM with the use of a cross-entropy technique, lead to a macro-consistent and disaggregated SAM. In particular, after constructing an aggregated SAM based on macro figures, parsimonious disaggregation of the accounts allows the researcher estimating the SAM to keep sight of the role that different types of information play. Right after each disaggregation, the accounts of the SAM are balanced, using information from local experts on which values are to be trusted in the case of major imbalances, and with the use of a cross-entropy technique that allows to perfectly balance the accounts while keeping the information on the SAM consistent with macro figures publicly available for the country.

Table 3 shows the numerical macro-SAM that we obtain in domestic currency for Pakistan after step 2, and Table 4 shows the data sources that need to be used in order to estimate it.

\subsection{Construction of the First Imbalanced Proto-SAM}

After estimating an aggregated SAM, the next step is to split the domestic value added into multiple sectors (51 sectors in the case at hand, as listed in the SAM accounts in Fig. 2). In doing this, we start from the value added by each major sector $(2007 / 2008$ gross national product at current factor cost), which sums to the value added in the macro-SAM, and split the sectors as follows:

1. Major and minor crops are disaggregated into wheat, rice, cotton, sugarcane, fruits and vegetables, and other field crops using the 2007/2008 data from Agricultural statistics of Pakistan, "Gross Value Addition of Major Crops at Current Factor Cost" and "Gross Value Addition of Minor Crops at Current Factor Cost" (Pakistan, Ministry of Food and Agriculture 2009).

2. Rice and wheat are further split using production of rice varieties and irrigated and nonirrigated wheat from Agricultural statistics of Pakistan.

3. Livestock is split into poultry and other livestock using the value of their output as identified by Agricultural statistics of Pakistan.

4. Manufacturing is split into vegetable oil, wheat milling, IRRI rice milling, basmati rice milling, refinement of sugar, other food, lint, yarn, cloth, knitwear, garments, other textiles, leather, wood, fertilizer, other chemicals, cement, petroleum refining, and other manufacturing using the most recent available Census of manufacturing industries (CMI) (FBS 2006).

5. Trade is split into wholesale, retail, and other using the Study on wholesale and retail trade, hotels and restaurants in Pakistan (FBS 2002).

6. Transport is split into road, rail, water, air, and other, such as transport by tubes, using National accounts of Pakistan: rebasing from 1980-81 to 1999-2000 (FBS 2004). 
Fig. 1 Suggested steps to build a SAM
Start with the schematic SAM in Table 2

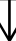

Use data sources (as listed in Table 4) to

construct an aggregated SAM (as in Table 3)

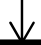

Construct first imbalanced proto-SAM by disaggregating sectors accounts

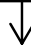

Estimate first partially balanced proto-SAM by conducting sector-specific adjustments on supply or demand to reduce imbalances

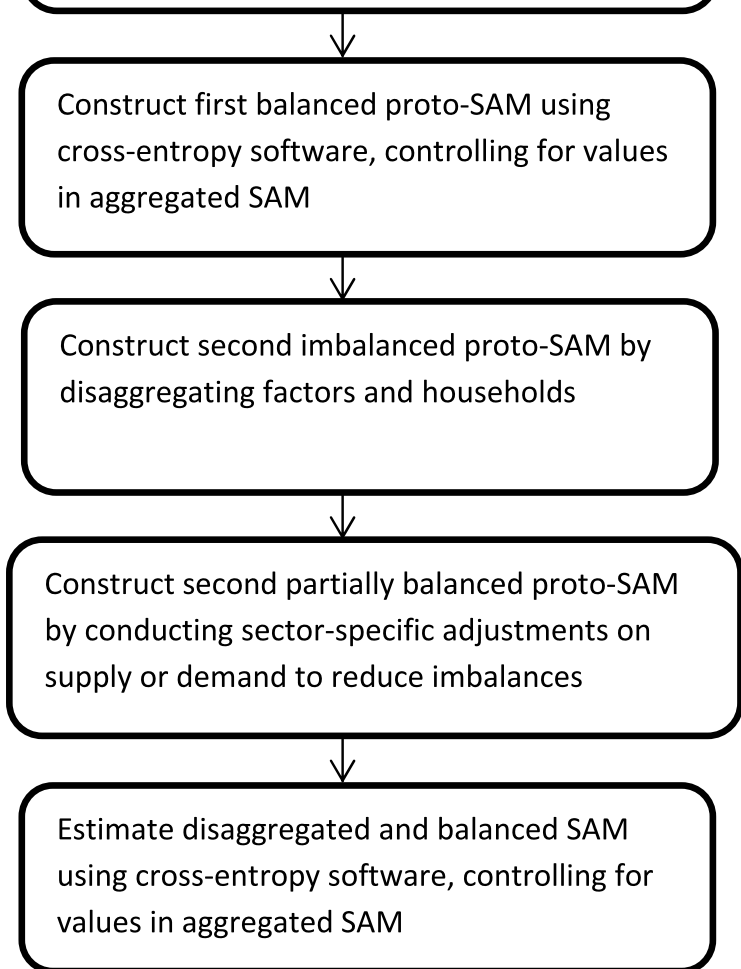

7. Housing is split into owned and non-owned using data from the Survey on community and personal services (FBS 2001).

8. "Social, community, and personal" services are split into business, education, health, personal, and other services using the same source. 
Table 2 A generic schematic SAM

\begin{tabular}{|c|c|c|c|c|c|c|c|c|c|c|}
\hline & Activities & Commodities & Land & Labor & Capital & Households & Government & $\begin{array}{l}\text { Change } \\
\text { in stocks }\end{array}$ & $\begin{array}{l}\text { Savings: } \\
\text { investment }\end{array}$ & $\begin{array}{l}\text { Rest of } \\
\text { the world }\end{array}$ \\
\hline Activities & & Supply matrix & & & & & & & & \\
\hline Commodities & $\begin{array}{l}\text { Intermediate } \\
\text { consumption }\end{array}$ & & & & & $\begin{array}{l}\text { Final private } \\
\text { consumption }\end{array}$ & $\begin{array}{l}\text { Final public } \\
\text { consumption }\end{array}$ & $\begin{array}{l}\text { Change } \\
\text { in stocks }\end{array}$ & $\begin{array}{l}\text { Fixed } \\
\text { investment }\end{array}$ & Exports \\
\hline Land & $\begin{array}{l}\text { Value added } \\
\text { by land }\end{array}$ & & & & & & & & & \\
\hline Labor & $\begin{array}{l}\text { Value added } \\
\text { by labor }\end{array}$ & & & & & & & & & \\
\hline Capital & $\begin{array}{l}\text { Value added } \\
\text { by capital }\end{array}$ & & & & & & & & & \\
\hline Households & & & $\begin{array}{l}\text { Payment from } \\
\text { land to } \\
\text { households }\end{array}$ & $\begin{array}{l}\text { Payment from } \\
\text { labor to } \\
\text { households }\end{array}$ & $\begin{array}{l}\text { Payment from } \\
\text { capital to } \\
\text { households }\end{array}$ & & $\begin{array}{l}\text { Transfers from } \\
\text { government to } \\
\text { households }\end{array}$ & & & $\begin{array}{l}\text { Remittance to } \\
\text { households }\end{array}$ \\
\hline Government & & $\begin{array}{l}\text { Sales and } \\
\text { imports tax }\end{array}$ & & & $\begin{array}{l}\text { Payment from } \\
\text { capital to } \\
\text { public sector }\end{array}$ & Direct taxes & & & & $\begin{array}{l}\text { Transfers from } \\
\text { nonresidents to } \\
\text { government }\end{array}$ \\
\hline $\begin{array}{l}\text { Change } \\
\text { in stocks }\end{array}$ & & & & & & & & & $\begin{array}{l}\text { Change in } \\
\text { stocks }\end{array}$ & \\
\hline $\begin{array}{l}\text { Savings: } \\
\text { investment }\end{array}$ & & & & & & $\begin{array}{l}\text { Household } \\
\text { savings }\end{array}$ & $\begin{array}{l}\text { Government } \\
\text { savings }\end{array}$ & & & Foreign savings \\
\hline $\begin{array}{l}\text { Rest of } \\
\text { the world }\end{array}$ & & Imports & & & $\begin{array}{l}\text { Repatriation } \\
\text { of dividends } \\
\text { and utilities }\end{array}$ & & $\begin{array}{l}\text { Government } \\
\text { payments to } \\
\text { nonresidents }\end{array}$ & & & \\
\hline
\end{tabular}


Table 3 Macro-SAM for Pakistan 2007/2008 (in billions of Pakistani rupees)

Activities Commodities Land Labor Capital Households Government Sales tax Import tax Direct tax Stocks Savings: Rest of Total investment the world

\begin{tabular}{|c|c|c|c|c|c|c|c|c|c|c|c|c|c|c|}
\hline Activities & & 25,743 & & & & & & & & & & & & 25,743 \\
\hline Commodities & 15,822 & & & & & 8,046 & 1,278 & & & & 164 & 2,095 & 1,502 & 28,907 \\
\hline Land & 576 & & & & & & & & & & & & & 576 \\
\hline Labor & 2,651 & & & & & & & & & & & & & 2,651 \\
\hline Capital & 6,695 & & & & & & & & & & & & & 6,695 \\
\hline Households & & & 576 & 2,651 & 5,998 & & 617 & & & & & & 763 & 10,605 \\
\hline Government & & & & & 442 & & & 171 & 151 & 391 & & & 27 & 1,181 \\
\hline Sales tax & & 171 & & & & & & & & & & & & 171 \\
\hline Import tax & & 151 & & & & & & & & & & & & 151 \\
\hline Direct tax & & & & & & 391 & & & & & & & & 391 \\
\hline Stocks & & & & & & & & & & & & 164 & & 164 \\
\hline $\begin{array}{l}\text { Savings: } \\
\text { investment }\end{array}$ & & & & & & 2,168 & -777 & & & & & & 868 & 2,259 \\
\hline $\begin{array}{l}\text { Rest of } \\
\text { the world }\end{array}$ & & 2,842 & & & 254 & & 63 & & & & & & & 3,160 \\
\hline Total & 25,743 & 28,907 & 576 & 2,651 & 6,695 & 10,605 & 1,181 & 171 & 151 & 391 & 164 & 2,259 & 3,160 & \\
\hline
\end{tabular}

Source: Pakistan National accounts and other data sources listed in Table 4 
Table 4 Sources of data for macro-SAM

Macro-SAM Source
item
Value added by land
National accounts, gross national product at current factor cost 2007/2008 of agricultural sectors (PBS 2012) multiplied by share of land in value added of agricultural sectors from Dorosh et al. (2004)

Value added by labor

Value added by capital

Intermediate consumption

Supply matrix

Direct tax

Import tax

Sales tax

Final public consumption

Change in stocks

Fixed investment

Exports

Imports

Final private consumption Payment from land to households Payment from labor to households Repatriation of dividends and utilities

Payment from capital to public sector

National accounts, gross national product at current factor cost 2007/2008 for each sector (PBS 2012) multiplied by share of labor in value added of sector in IO matrix (FBS 1991)

National accounts, gross national product at current factor cost 2007/2008 (PBS 2012) minus two above

National accounts, gross national product at current factor cost 2007/2008 for each sector (PBS 2012) multiplied by ratio of intermediate consumption and value added in those activities in IO matrix (FBS 1991) ${ }^{\mathrm{a}}$

Sum of payments above

Pakistan, Ministry of Finance (2009), "Fiscal Development" item "Direct Taxes" 2007/2008

Pakistan, Ministry of Finance (2009), Pakistan: Summary of Consolidated Federal and Provincial Revenue 2007-2008, Taxes on International Trade

Table 1.4 in State Bank of Pakistan (2010), Indirect Taxes - Subsidies - Import Tax

Table 1.4 in State Bank of Pakistan (2010), General Government Consumption Expenditure FY08

Table 1.4 in State Bank of Pakistan (2010), Changes in Stocks FY08

Table 1.4 in State Bank of Pakistan (2010), Gross Domestic Fixed Capital Formation FY08

Table 2 in IMF (2010), Pakistan: Balance of Payments, 2007-2008. "Exports: FOB" + "Services: Credit"

Table 2 in IMF (2010), Pakistan: Balance of Payments, 2007-2008. "Imports: FOB" + "Services: Debit"

Residual of commodity account

Value added by land

Value added by labor

Table 2 in IMF (2010), Pakistan: Balance of Payments 2007-2008. "Income:

Debit" + "Current Transfers: Debit" - "Income: Credit"

Table 3.7 in State Bank of Pakistan (2010), Residual of Public Incomes

We subsequently split the value added of each of these sectors into a payment to land, a payment to capital, and a payment to labor. For crops, we use the factor shares at the activity level in the cost of production of Pakistan (2003) as informed by the Agriculture Policy Institute (Agricultural Prices Commission 2003). For the 
Table 4 (Continued)

\begin{tabular}{ll}
\hline $\begin{array}{l}\text { Macro-SAM } \\
\text { item }\end{array}$ & Source \\
\hline $\begin{array}{l}\text { Government } \\
\text { savings }\end{array}$ & $\begin{array}{l}\text { Pakistan, Ministry of Finance (2009), Pakistan: Summary of Consolidated Federal } \\
\text { and Provincial Budgetary Operations, Provisional, Table 1, Budget Deficit } \\
\text { 2007-2008 } \\
\text { Table 3a in IMF (2010), Share of Foreign into Total Payment of Interest by GOP } \\
\text { Government } \\
\text { payments to } \\
\text { nonresidents }\end{array}$ \\
$\begin{array}{l}\text { Pakistan (2010), Interest Payment FY08 Consolidated Federal and Provincial } \\
\text { Governments }\end{array}$ \\
$\begin{array}{l}\text { Tansfer from } \\
\text { nonresidents to } \\
\text { government } \\
\text { Transfer from } \\
\text { government to } \\
\text { households }\end{array}$ & Rovernment in Balance of Payments FY08 \\
\hline
\end{tabular}

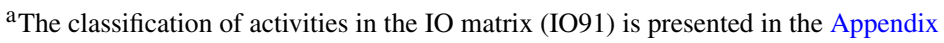

remaining activities, where land does not add value, the shares of labor and capital are identified by the most updated IO matrix (FBS 1991) and the sectors in the IO matrix are mapped to those in the SAM using Table 5. Then we split the intermediate use of each activity among commodities using recent information on the production costs of crops (Agricultural Prices Commission 2009) and the IO matrix.

The supply of each activity sector is allocated to its corresponding commodity. ${ }^{2}$ The sector composition of private final consumption is informed by expenditures present in the Household Income and Expenditure Survey (HIES) (FBS 2008), expanded with the sample household weights, and using Table 6. The sector composition of fixed investment, changes in stocks, and public final consumption is informed by the IO matrix and the respective mapping into SAM accounts (Table 5). The sector composition of imports and exports is informed mainly by 2007/2008 trade data from the Pakistan Economic Survey (Pakistan, Ministry of Finance 2009), and 2008 import data from the Pakistani Ministry of Commerce (Pakistan, Ministry of Commerce 2011) and United Nations Conference on Trade and Development (UNCTAD 2008). Commodity-specific import revenue is estimated by multiplying the value of imports of each commodity and the associated tariff rates available for Pakistan from the Federal Board of Revenue (FBR 2008). The sales tax is split among commodities in proportion to the already calculated production value of each commodity.

\subsection{Balancing the First Proto-SAM}

At this stage, relatively large imbalances are found in lint, mining, construction, and business services. Relying on supply information provided by CMI and consultation

\footnotetext{
${ }^{2}$ Given data availability, secondary production is ignored. A slight modification in the procedure would be needed if data on secondary production were available.
} 


\begin{abstract}
Activities (51)
Agriculture (12): Wheat irrigated, wheat nonirrigated, rice-IRRI (irrigated), rice-basmati (irrigated), cotton (irrigated), sugarcane (irrigated), other field crops, fruits/vegetables, livestock (cattle, milk), livestock (poultry), forestry, fishing

Industry (22): Mining, vegetable oils, wheat milling, rice milling (IRRI), rice milling (basmati), sugar, other food, cotton gin (lint), cotton spin (yarn), cotton weave (cloth), knitwear, garments, other textiles, leather, wood, chemicals, fertilizers, cement and bricks, petroleum refining, other manufacturing, energy, construction

Services (17): Trade-wholesale, trade-retail, trade-other, transport-rail, transport-road, transport—water, transport—air, transport—other, housing, imputed rent, business services, healthcare, education, personal services, other private services, public services, finance and insurance
\end{abstract}

\title{
Commodities (50)
}

Same as activities, except wheat irrigated and wheat nonirrigated activities aggregated as one commodity (wheat)

\section{Factors (27)}

Labor (10): Own-farm (large farm, medium farm Sindh, medium farm Punjab, medium farm other Pakistan, small farm Sindh, small farm Punjab, small farm other Pakistan), agricultural waged, nonagricultural unskilled, nonagricultural skilled

Land (12): Large farm (Sindh, Punjab, other Pakistan), irrigated medium farm (Sindh, Punjab, other Pakistan), irrigated small farm (Sindh, Punjab, other Pakistan), nonirrigated small farm (Sindh, Punjab, other Pakistan)

Other factors (5): Water, capital livestock, capital other-agriculture, capital formal, capital informal

\section{Households (18)}

Rural (15): Large/medium farm (Sindh, Punjab, other Pakistan), small farm (Sindh, Punjab, other Pakistan), landless unwaged farmer (Sindh, Punjab, other Pakistan), landless waged farmer (Sindh, Punjab, other Pakistan), rural nonfarm per capita expenditure quintile 1, quintile 2, and rest

Urban (3): Per capita expenditure quintile 1, quintile 2, and rest

\section{Other Institutional Accounts (4)}

Government (including separate subaccounts for import taxes, direct taxes, and sales taxes), rest of world, savings-investment, change in stocks

Fig. 2 Accounts in the SAM

with local experts, we perform a series of adjustments mostly on the final consumption and investment of the commodities that reduce the imbalances at the commodity level to less than $30 \%$ of the average between supply and use. We then balance this proto-SAM, seeking to minimize the cross-entropy distance between the first partially imbalanced and balanced proto-SAMs, imposing the series of controls present in the macro-SAM. Following the approach described in Golan et al. (1994), we treat every cell in the proto-SAM as being specified with an error support set whose weights are estimated to minimize the cross-entropy distance between the prior and the solution proto-SAM. This treatment is strongly related to the one described in Robinson et al. (2001), with key differences. In the previous approach, the column coefficients in the SAM were treated analogously to probabilities and included directly in the crossentropy minimand, creating the need for special treatment of negative cells and accounts with zero sums in the SAM. In the approach we apply, developed by Sherman Robinson and Scott McDonald - starting from Robinson et al. (2001) — the crossentropy minimand includes only probability weights for a selected error support set, such that the SAM coefficients are no longer treated as analogous to probabilities, and 
Table 5 Mapping of the sectors in the input-output matrix (IO91) to those in the SAM

\begin{tabular}{|c|c|c|c|}
\hline Sectors in 1091 & SAM 2007/2008 Sectors & Sectors in IO9I & SAM 2007/2008 Sectors \\
\hline 2 & Wheat (irrigated) & 37 & Wood \\
\hline 2 & Wheat (nonirrigated) & $39,41,44$ & Chemicals \\
\hline 1 & Rice (IRRI) & 40 & Fertilizers \\
\hline 1 & Rice (basmati) & 45,46 & Cement and bricks \\
\hline 3 & Cotton & 42 & Petroleum refining \\
\hline 4 & Sugarcane & $38,43,47-57$ & Other manufacturing \\
\hline $6,7,11,12$ & Other field crops & 58,59 & Energy \\
\hline $8,9,10$ & Fruits and vegetables & 60 & Construction \\
\hline 13 & Livestock (cattle, milk) & 61 & Wholesale trade \\
\hline 13 & Livestock (poultry) & 62 & Retail trade \\
\hline 14 & Forestry & 63 & Other trade \\
\hline 15 & Fishing & 64,69 & Railway transport \\
\hline $16,17,18$ & Mining & 65 & Road transport \\
\hline 19 & Vegetable oils & 66 & Water transport \\
\hline 20 & Wheat milling & 67 & Air transport \\
\hline 20 & Rice milling (IRRI) & 68 & Other transport \\
\hline 20 & Rice milling (basmati) & 75 & Housing \\
\hline 22 & Sugar & 76 & Imputed rent \\
\hline $5,21,23,24,25$ & Other food & 77 & Business services \\
\hline 26 & Cotton gin (lint) & 80 & Healthcare \\
\hline 27 & Cotton spin (yarn) & 79 & Education \\
\hline 28 & Cotton weave (cloth) & 82 & Personal services \\
\hline 31 & Knitwear & 81 & Other private services \\
\hline $32,33,34$ & Garments & 70,78 & Public services \\
\hline 29,30 & Other textiles & $71,72,74$ & Finance and insurance \\
\hline
\end{tabular}

negative entries and accounts with zero sums do not require any special treatment. ${ }^{3}$ The present approach allows specification of a prior estimate of the mean and standard error of selected cell entries (expressed either as values or column coefficients), column sums, and macro aggregates. These errors can be specified as additive or multiplicative-exponential. For the aggregates present in the Pakistan macro-SAM, we set a zero standard error. This, unlike previous approaches, allows us to arrive at a SAM that is perfectly consistent with the macro-SAM, such that the sum of the value added in the solution SAM is exactly equal to the gross national product at factor cost in the macro-SAM; the private final consumption in the solution SAM sums exactly the private final consumption in the macro-SAM, and similarly for public consumption in goods and services, investment, total exports, and total imports.

\footnotetext{
${ }^{3}$ The associated GAMS (General Algebraic Modeling System) code is available from the authors upon request. 
Table 6 Mapping the commodities in the Household Income and Expenditure Survey (HIES) to the sectors in the SAM

\begin{tabular}{ll}
\hline Commodities in HIES & SAM 2007/2008 Commodities \\
\hline $2103-2104,2201-2206$ & Other field crops \\
$1301-1308,1501-1510$ & Fruits and vegetables \\
$1101-1103,1201-1202$ & Livestock (cattle, milk) \\
$1203-1204$ & Livestock (poultry) \\
1205 & Fish \\
$2301-2303$ & Vegetable oils \\
$2101,2502,2503$ & Wheat flour \\
Part of 2102 & Rice (IRRI) \\
Part of 2102 & Rice (basmati) \\
1701 & Sugar \\
$1803,2105,2501,2504,2601$ & Other food \\
6103 & Cotton cloth \\
5103 & Knitwear \\
$5101-5102,5104-5105$ & Garments \\
6102,6104 & Other textiles \\
$5201-5202$ & Leather \\
2701 & Wood \\
5601 & Chemicals \\
4301 & Petroleum \\
$6101,6302-6303,6305,6401,6403-6404$ & Other manufacturing goods \\
$2702-2707,2709$ & Energy \\
2406 & Construction \\
4303 & Railway transport \\
$4302,4304,6505$ & Road transport \\
5705 & Air transport \\
$5401-5402,5405$ & Housing \\
$5403-5404$ & Imputed rent \\
5602 & Healthcare \\
$5801-5804$ & Education \\
$2901-2903$ & Personal services \\
$4401,5903-5904$ & Other private services \\
\hline &
\end{tabular}

\subsection{Disaggregating the Payments Related to Factors and Households}

To fully disaggregate the incomes and payments of the single household group and the three factors (labor, capital, and land) of the first balanced proto-SAM into the complete set of factors and households of the SAM, we take the following steps. The value added of each activity is split among the (27) factors using the shares present in DNN, in turn partly informed by the Pakistan Rural Household Survey (PRHS) (Pakistan Institute of Development Economics 2001). 
After this, regarding payments from factors to institutions, payments from capital to government and to nonresidents are taken directly from the macro-SAM and attributed to formal capital. The matrix of household incomes is split as follows. Household income from labor, agricultural capital, and nonagricultural formal capital is split among households following household incomes in HIES; livestock income is split following the value of the livestock capital stock owned by households in HIES; and land and water income is split among households following DNN.

Income from informal nonagricultural capital (which includes returns to selfemployed labor in informal-sector activities) is split between rural and urban households, using as proxy the share of rural population in total population as informed by HIES $(67 \%)$. The further split across rural households uses reported incomes from nonfarm enterprises in a rural household survey (PRHS) and updated household population totals (HIES). The remaining (33\%) nonagricultural wage income is allocated between urban nonpoor and poor households following DNN. ${ }^{4}$ In the absence of detailed and reliable information, returns to agricultural capital are split among households in proportion to their land income, and public transfers and remittances to households informed in the macro-SAM are allocated among households in proportion to their total expenditures.

Final private consumption of each commodity is split among the (18) household groups using HIES. We assume that the more disadvantaged households are able to save a lower share of their income. A relatively high (15\%) savings rate is used as a prior for medium/large farms and nonfarm households (quintiles 3 to 5), and a relatively low (7\%) savings rate is assumed for the remaining households except for the "other urban" households (quintiles 3 to 5), an account that also captures enterprise savings. For this last household category, the savings rate is determined residually from the domestic private savings figure in the macro-SAM (37.5\%).

\subsection{Balancing the Final SAM}

After a series of adjustments to the less reliable parts of the household accounts (informal capital household income and nonfood household expenditures) based on consultation with local experts to reduce the imbalances at the household level to less than 30 percent of the average between their total income and total expenditure, the cross-entropy balancing code is run, imposing once again the series of controls present in the macro-SAM. This is the last step in the estimation of a balanced, macroconsistent, and largely disaggregated SAM that captures the economic structure of the country in an updated way and with a significant degree of detail.

\section{Structure of the Pakistani Economy: Observations from the SAM}

The structure of value added (Table 7) is characteristic of a semi-industrialized economy with a relatively low share of agriculture $(20 \%)$ and large shares of industry and

\footnotetext{
${ }^{4}$ Estimates of earnings from informal enterprises are perhaps the most uncertain figures in the SAM. Income data from the PRHS 2001/2002 appear to seriously underreport these earnings for rural households. If per capita informal-sector earnings from the PRHS 2001/2002 are used as the basis for calculating total earnings in rural areas, the share of rural households in total informal-sector earnings is only 7.2 percent.
} 
Table 7 Structure of the economy, 2007/2008

\begin{tabular}{|c|c|c|c|c|c|c|}
\hline & $\begin{array}{l}\text { Output } \\
(\%)\end{array}$ & $\begin{array}{l}\text { Value added } \\
(\%)\end{array}$ & $\begin{array}{l}\text { Export } \\
(\%)\end{array}$ & $\begin{array}{l}\text { Import } \\
(\%)\end{array}$ & $\begin{array}{l}\text { Export/output } \\
(\%)\end{array}$ & $\begin{array}{l}\text { Import/domestic } \\
\text { absorption } \\
(\%)\end{array}$ \\
\hline Agricultural sector & 12.1 & 20.3 & 1.6 & 3.0 & 0.9 & 2.9 \\
\hline Crops & 5.7 & 8.9 & 0.8 & 2.8 & 0.9 & 5.7 \\
\hline Livestock & 5.9 & 10.6 & 0.2 & 0.2 & 0.2 & 0.4 \\
\hline Fishing & 0.4 & 0.5 & 0.7 & - & 12.5 & - \\
\hline Forestry & 0.1 & 0.3 & - & - & - & - \\
\hline Industrial sector & 47.3 & 26.8 & 67.2 & 76.2 & 9.2 & 17.8 \\
\hline Mining and quarrying & 2.6 & 3.0 & 0.0 & 10.7 & 0.0 & 33.4 \\
\hline Manufacturing & 38.9 & 19.7 & 67.2 & 65.5 & 11.2 & 18.8 \\
\hline Electricity, gas, and water distribution & 1.2 & 1.5 & - & - & - & - \\
\hline Construction & 4.6 & 2.6 & - & - & - & - \\
\hline Services sector & 40.7 & 52.9 & 31.1 & 20.8 & 4.9 & 6.2 \\
\hline Wholesale and retail & 10.3 & 18.4 & 0.1 & 0.6 & 0.1 & 0.7 \\
\hline Transport and communication & 14.0 & 11.7 & 14.9 & - & 6.8 & - \\
\hline Ownership of dwellings & 1.3 & 2.4 & - & - & - & - \\
\hline Public administration and defense & 5.9 & 5.3 & - & - & - & - \\
\hline Social, community, and private services & 6.7 & 9.4 & 16.1 & 20.2 & 15.6 & 30.5 \\
\hline Financial services & 2.5 & 5.6 & - & - & - & - \\
\hline Total & 100.0 & 100.0 & 100.0 & 100.0 & 6.5 & 11.6 \\
\hline
\end{tabular}


services ( $27 \%$ and $53 \%$, respectively). Livestock accounts for more than half of the value added in the agricultural sector. Much of the industrial production is strongly linked to agriculture, including wheat, rice and sugar milling, and textile production (linked to cotton). ${ }^{5}$ Trade (wholesale and retail) and transport generate more than half of the value added in services. Exports are a relatively low share of total output $(6.5 \%)$; imports are concentrated in the industrial sector (including petroleum products, part of the mining sector) and in private services (particularly business services).

Table 8 shows the composition of value added across sectors. For agricultural products, land is the largest component of value added. Manufacturing activities depend heavily on formal capital, while labor and other capital are important for most services.

Large and medium farmers in Pakistan earn a large share of their income from land (Table 9). However, small and landless farmers rely on labor, livestock, and other capital for most of their income. Rural nonfarm and urban households rely mostly on their labor and other capital as sources of income.

The importance of agricultural income by household group is generally lower in the recent SAM than in the PRHS of 2001/2002, suggesting that households have more diversified income sources than are revealed by PRHS data (Table 10). This is consistent with the tendency toward diversification of rural incomes found using different spans of HIES: income from crop production as a share of total income in rural Pakistan was $22.9 \%$ in HIES 2001/2002 and 21.5\% in HIES 2007/2008. In addition, PRHS 2000/2001 had a relatively detailed module on agricultural production, which may have allowed it to capture the existing agricultural income to a larger extent. The SAM also shows that agricultural income accounts for a large share of the income of farmers - especially for medium and large farms - which is consistent with PRHS data.

\section{Income Multiplier Analysis}

To illustrate the use of the SAM, we use income multiplier analysis. To capture the production and consumption linkages, taking into account the supply rigidities present in Pakistan, we use a semi-input-output model with constrained linear relationships among quantities in the model and fixed prices. In this approach, sectors are classified into two groups: those that are supply constrained and those that are supply responsive. Output responses are permitted only in supply-responsive sectors. For this model to produce a suitable approximation of reality, the supply-constrained sectors must correspond to tradable goods. Therefore, in the approach we follow, the imbalances between supply and demand in these sectors are solved via changes in net exports.

The starting point is the sector-specific equilibrium conditions, that is, $x_{c}(1+$ $\left.t c_{c}\right)=\sum_{c^{\prime}} z_{c c^{\prime}}+\sum_{h} c_{c h}+g_{c}+i_{c}+e_{c}$, where $x_{c}$ is precommodity-tax gross output, $t c_{c}$ is commodity tax rate, $z_{c c^{\prime}}$ is intermediate demand of good $c$ by sector $c^{\prime}, c_{c h}$ is household consumption of good $c$ by household $h, g_{c}$ is public consumption of

${ }^{5}$ Not tabulated. 
Table 8 Composition of value added

\begin{tabular}{|c|c|c|c|c|c|c|c|}
\hline & $\begin{array}{l}\text { Land } \\
(\%)\end{array}$ & $\begin{array}{l}\text { Labor } \\
(\%)\end{array}$ & $\begin{array}{l}\text { Livestock } \\
(\%)\end{array}$ & $\begin{array}{l}\text { Formal capital } \\
(\%)\end{array}$ & $\begin{array}{l}\text { Other capital } \\
(\%)\end{array}$ & $\begin{array}{l}\text { Total } \\
(\%)\end{array}$ & $\begin{array}{l}\text { GDP } \\
(\%)\end{array}$ \\
\hline Agricultural sector & 28.6 & 15.9 & 37.8 & 11.4 & 6.3 & 100.0 & 20.1 \\
\hline Crops & 63.5 & 27.0 & 0.0 & 0.0 & 9.5 & 100.0 & 8.9 \\
\hline Livestock & 0.0 & 6.7 & 72.6 & 20.7 & 0.0 & 100.0 & 10.6 \\
\hline Fishing & 0.0 & 18.3 & 0.0 & 23.4 & 58.4 & 100.0 & 0.5 \\
\hline Forestry & 50.0 & 5.7 & 0.0 & 0.0 & 44.3 & 100.0 & 0.3 \\
\hline Industrial sector & 0.0 & 25.9 & 0.0 & 60.7 & 13.5 & 100.0 & 26.9 \\
\hline Mining and quarrying & 0.0 & 72.0 & 0.0 & 28.0 & 0.0 & 100.0 & 3.0 \\
\hline Manufacturing & 0.0 & 16.9 & 0.0 & 68.4 & 14.7 & 100.0 & 19.7 \\
\hline Electricity, gas, and water distribution & 0.0 & 15.6 & 0.0 & 84.4 & 0.0 & 100.0 & 1.5 \\
\hline Construction & 0.0 & 45.4 & 0.0 & 27.3 & 27.3 & 100.0 & 2.6 \\
\hline Services sector & 0.0 & 26.7 & 0.0 & 24.6 & 48.6 & 100.0 & 53.0 \\
\hline Wholesale and retail & 0.0 & 8.9 & 0.0 & 27.3 & 63.8 & 100.0 & 18.5 \\
\hline Transport and communication & 0.0 & 24.2 & 0.0 & 22.7 & 53.1 & 100.0 & 11.7 \\
\hline Ownership of dwellings & 0.0 & 8.9 & 0.0 & 30.2 & 60.9 & 100.0 & 2.4 \\
\hline Public administration and defense & 0.0 & 64.2 & 0.0 & 35.8 & 0.0 & 100.0 & 5.4 \\
\hline Social, community, and private services & 0.0 & 49.9 & 0.0 & 15.0 & 35.1 & 100.0 & 9.4 \\
\hline Financial services & 0.0 & 23.7 & 0.0 & 22.9 & 53.4 & 100.0 & 5.6 \\
\hline
\end{tabular}


Table 9 Household income shares

\begin{tabular}{|c|c|c|c|c|c|c|c|c|c|}
\hline & $\begin{array}{l}\text { Land } \\
(\%)\end{array}$ & $\begin{array}{l}\text { Labor } \\
(\%)\end{array}$ & $\begin{array}{l}\text { Livestock } \\
(\%)\end{array}$ & $\begin{array}{l}\text { Formal capital } \\
(\%)\end{array}$ & $\begin{array}{l}\text { Other capital } \\
(\%)\end{array}$ & $\begin{array}{l}\text { Government } \\
(\%)\end{array}$ & $\begin{array}{l}\text { Nonresidents } \\
(\%)\end{array}$ & $\begin{array}{l}\text { Total } \\
(\%)\end{array}$ & $\begin{array}{l}\text { National income } \\
(\%)\end{array}$ \\
\hline Large and medium farm-Sindh & 57.7 & 11.0 & 7.4 & 0.0 & 16.0 & 4.8 & 3.2 & 100.0 & 1.5 \\
\hline Large and medium farm-Punjab & 31.8 & 9.2 & 14.0 & 0.0 & 37.3 & 4.2 & 3.5 & 100.0 & 6.2 \\
\hline Large and medium farm-other & 42.5 & 19.7 & 4.2 & 0.0 & 27.9 & 2.8 & 3.0 & 100.0 & 0.8 \\
\hline Small farm—Sindh & 15.1 & 12.2 & 18.4 & 0.0 & 37.6 & 8.5 & 8.3 & 100.0 & 1.8 \\
\hline Small farm-Punjab & 11.4 & 9.6 & 24.1 & 0.0 & 39.0 & 7.8 & 8.1 & 100.0 & 11.5 \\
\hline Small farm-other & 9.3 & 16.9 & 11.1 & 0.0 & 47.9 & 7.0 & 7.9 & 100.0 & 3.3 \\
\hline Landless farmer-Sindh & 11.5 & 10.0 & 21.1 & 0.0 & 41.8 & 7.0 & 8.5 & 100.0 & 1.4 \\
\hline Landless farmer-Punjab & 8.2 & 13.9 & 37.1 & 0.0 & 25.5 & 7.3 & 8.0 & 100.0 & 1.8 \\
\hline Landless farmer-other & 5.7 & 16.5 & 18.1 & 0.0 & 43.8 & 7.1 & 8.6 & 100.0 & 0.8 \\
\hline Landless agricultural laborers-Sindh & 0.0 & 21.7 & 3.5 & 0.0 & 59.7 & 6.6 & 8.6 & 100.0 & 1.5 \\
\hline Landless agricultural laborers-Punjab & 0.0 & 21.0 & 11.9 & 0.0 & 53.4 & 6.1 & 7.7 & 100.0 & 1.4 \\
\hline Landless agricultural laborers-other & 0.0 & 33.7 & 1.8 & 0.0 & 49.8 & 6.3 & 8.4 & 100.0 & 0.2 \\
\hline Rural nonfarm quintile 1 & 0.0 & 36.1 & 6.7 & 0.0 & 46.3 & 4.9 & 6.0 & 100.0 & 2.8 \\
\hline Rural nonfarm quintile 2 & 0.0 & 38.9 & 8.5 & 0.0 & 39.3 & 6.1 & 7.3 & 100.0 & 3.3 \\
\hline Rural nonfarm other & 0.0 & 36.3 & 5.4 & 0.0 & 42.7 & 7.3 & 8.3 & 100.0 & 17.3 \\
\hline Urban quintile 1 & 0.0 & 59.8 & 0.0 & 0.0 & 25.3 & 6.9 & 8.0 & 100.0 & 2.6 \\
\hline Urban quintile 2 & 0.0 & 63.2 & 0.0 & 0.0 & 21.2 & 7.2 & 8.4 & 100.0 & 3.4 \\
\hline Urban other & 0.0 & 16.8 & 0.0 & 59.7 & 12.2 & 4.4 & 6.9 & 100.0 & 38.5 \\
\hline Rural farm subtotal & 16.9 & 12.3 & 18.1 & 0.0 & 39.2 & 6.6 & 6.9 & 100.0 & 32.1 \\
\hline Rural nonfarm subtotal & 0.0 & 36.7 & 6.0 & 0.0 & 42.7 & 6.8 & 7.9 & 100.0 & 23.4 \\
\hline Urban subtotal & 0.0 & 22.9 & 0.0 & 51.7 & 13.6 & 4.8 & 7.1 & 100.0 & 44.5 \\
\hline Total households & 5.4 & 22.7 & 7.2 & 23.0 & 28.6 & 5.8 & 7.2 & 100.0 & 100.0 \\
\hline
\end{tabular}

Source: Authors' calculations using 2007/2008 SAM for Pakistan 
Table 10 Rural agricultural incomes

\begin{tabular}{lcc}
\hline Household group & $\begin{array}{l}\text { Share of agricultural } \\
\text { income in PRHS } \\
(\%)\end{array}$ & $\begin{array}{l}\text { Share of agricultural } \\
\text { income in SAM } \\
(\%)\end{array}$ \\
\hline Medium and large farms & 83.5 & 66.0 \\
Small farms & 67.9 & 41.2 \\
Landless farmers & 87.7 & 45.6 \\
Rural agricultural workers & 53.1 & 22.2 \\
Rural nonfarm nonpoor & 1.9 & 6.7 \\
Rural nonfarm poor & 6.3 & 9.7 \\
Rural agricultural & 74.8 & 46.5 \\
Rural & 69.7 & 30.1 \\
\hline
\end{tabular}

Source: Authors' calculations using PRHS 2001/2002 and 2007/2008 SAM for Pakistan

good $c, i_{c}$ is investment (fixed and change in stock) demand for good $c$, and $e_{c}$ is net export of good $c$. Intermediate and factor demand are assumed to be proportional to output production, that is, $z_{c c^{\prime}}=a_{c c^{\prime}} x_{c^{\prime}}$ and $v_{f c^{\prime}}=a_{f c^{\prime}} x_{c^{\prime}}$, where $a_{c c^{\prime}}$ and $a_{f c^{\prime}}$ are the requirements of intermediate input $c^{\prime}$ and factor $f$ to produce a unit of $c$. Household consumption is given by $c_{c h}=\theta_{c h}\left(1-t h_{h}\right) y_{h}$, where $y_{h}$ is pretax income of household $h, t h_{h}$ is the corresponding tax rate, and $\theta_{c h}$ is the share of post-tax income of household $h$ spent on commodity $c$. Finally, pretax household income is the sum of factor income and transfers received by the household from other agents, that is, $y_{h}=\sum_{f} a_{h f} v_{f}+t r_{h}$, with $v_{f}=\sum_{c} v_{f c}$, and $a_{h f}$ being the share of household $h$ in the income of factor $f$.

Replacing the intermediate and factor demand and household demand function in the equilibrium condition, we find that $x_{c}\left(1+t c_{c}\right)=\sum_{c^{\prime}}\left(a_{c c^{\prime}} x_{c^{\prime}}\right)+\sum_{h}\left\{\theta_{c h}(1-\right.$ $\left.\left.t h_{h}\right)\left[\sum_{f}\left(a_{h f}\left(\sum_{c^{\prime}} a_{f c^{\prime}} x_{c^{\prime}}\right)\right)+t r_{h}\right]\right\}+g_{c}+i_{c}+e_{c}$, which can be solved either for $x_{c}$ (demand-constrained sector) or for $e_{c}$ (supply-constrained sector), fixing either $e_{c}$ (demand-constrained sector) or $x_{c}$ (supply-constrained sector).

We conduct a series of simulations in which a constant injection is applied to the economy (100 billion rupees during the year), either to supply (supply-constrained sector) or to net export demand (remaining sectors). We run a simulation focusing the injection only on crops, where each crop receives the proportion of the total injection based on its share in the total value added of crops. We then do the same for livestock, industry, services, and all sectors, totaling five simulations. Finally, we divide the absolute changes in output values by the injection, obtaining the output multipliers shown in Table 11. All aggregate output multipliers are in the 1.1-1.4 range, with livestock and industry having the highest output multipliers. These multipliers are significantly below the multipliers found for India by Pal et al. (2012), probably reflecting the fact that their analysis assumes the absence of supply rigidities, which we seek to capture here. Our estimates are aligned with the 1.5 value-added multiplier reported in Dorosh et al. (2003), Haggblade et al. (1991), and Mellor (1995). As expected, the output multipliers are largest in the sectors where the injection takes place (main diagonal of the table). We also find that the direct effects are larger than 
Table 11 Output multipliers for sector-specific simulations (rupees of sector output change per rupee of injection)

\begin{tabular}{llllll}
\hline & $\begin{array}{l}\text { Crops } \\
\text { simulation }\end{array}$ & $\begin{array}{l}\text { Livestock } \\
\text { simulation }\end{array}$ & $\begin{array}{l}\text { Industry } \\
\text { simulation }\end{array}$ & $\begin{array}{l}\text { Services } \\
\text { simulation }\end{array}$ & $\begin{array}{l}\text { All sectors } \\
\text { simulation }\end{array}$ \\
\hline Crops & 1.007 & 0.054 & 0.053 & 0.000 & 0.110 \\
Livestock & 0.004 & 0.991 & 0.003 & 0.005 & 0.109 \\
Industry & 0.139 & 0.020 & 1.049 & 0.024 & 0.308 \\
Services & 0.077 & 0.259 & 0.226 & 1.135 & 0.696 \\
Total & 1.227 & 1.324 & 1.337 & 1.165 & 1.233 \\
\hline
\end{tabular}

Source: Authors' semi-input-output analysis based on Pakistan SAM 2007/2008

the indirect effects, that most of the indirect effects are concentrated in the service sector (a significant supplier to the other sectors, especially in the case of trade and transport),${ }^{6}$ and that the injection in the service sector has the lowest output multiplier for the entire economy.

These injections significantly change the distribution of income among households in light of the economic structure of Pakistan, as the income multipliers in Table 12 show. A direct injection in the crops sector especially benefits small and medium/large farms in Punjab, where a large share of crop production is concentrated (particularly wheat, cotton, and horticulture). Higher production of livestock especially benefits the small farms in Punjab-which receive around 38 percent of total livestock income-and, to a lesser extent, the top three quintiles of the urban sector, which own most of the formal capital used in the livestock sector. An injection in the industrial sector leads to significantly higher imports of petroleum and manufactured goods, leading to a reduced total household income multiplier (only 0.44) and to benefits especially for the top three quintiles of the urban sector, which own most of the capital stock. Given that services use skilled labor in a relatively intensive way (compared to other sectors) and that most of the skilled labor is found in the top three quintiles of the rural nonfarm and urban socioeconomic groups, an injection in the service sector benefits these groups in particular. Finally, given the large share of the service sector in the Pakistani economy (53\% of its value added), a generalized injection also ends up benefiting in particular these two socioeconomic groups, though the small farms of Punjab benefit to some extent as well.

\section{Conclusions}

This paper has provided future researchers of economic structure with a model for building a SAM, that is, a unique countrywide database for use in structural analysis. It has also applied this model to the empirical investigation of the economic structure of Pakistan. Thus, this work is an attempt to provide a useful reference and resource for academics concerned with economic structure, particularly that of Pakistan.

\footnotetext{
${ }^{6}$ The only exception is the injection in crops, with the largest indirect effect seen in industry.
} 
Table 12 Household income multipliers for sector-specific simulations (rupees of household income change per thousand rupees of injection)

\begin{tabular}{|c|c|c|c|c|c|}
\hline & $\begin{array}{l}\text { Crops } \\
\text { simulation }\end{array}$ & $\begin{array}{l}\text { Livestock } \\
\text { simulation }\end{array}$ & $\begin{array}{l}\text { Industry } \\
\text { simulation }\end{array}$ & $\begin{array}{l}\text { Services } \\
\text { simulation }\end{array}$ & $\begin{array}{l}\text { All sectors } \\
\text { simulation }\end{array}$ \\
\hline Large and medium farm-Sindh & 92 & 15 & 7 & 2 & 13 \\
\hline Large and medium farm-Punjab & 220 & 87 & 19 & 31 & 51 \\
\hline Large and medium farm—other & 42 & 4 & 3 & 3 & 7 \\
\hline Small farm-Sindh & 36 & 26 & 4 & 8 & 11 \\
\hline Small farm-Punjab & 155 & 215 & 21 & 49 & 69 \\
\hline Small farm-other & 41 & 35 & 8 & 23 & 22 \\
\hline Landless farmer-Sindh & 21 & 21 & 3 & 6 & 8 \\
\hline Landless farmer-Punjab & 22 & 49 & 3 & 7 & 12 \\
\hline Landless farmer-other & 7 & 10 & 1 & 4 & 4 \\
\hline Landless agricultural laborers-Sindh & 7 & 14 & 2 & 8 & 7 \\
\hline Landless agricultural laborers_-Punjab & 5 & 21 & 3 & 12 & 10 \\
\hline Landless agricultural laborers-other & 1 & 2 & 0 & 1 & 1 \\
\hline Rural nonfarm quintile 1 & 3 & 20 & 9 & 29 & 21 \\
\hline Rural nonfarm quintile 2 & 3 & 27 & 11 & 31 & 23 \\
\hline Rural nonfarm other & 13 & 94 & 55 & 137 & 99 \\
\hline Urban quintile 1 & 2 & 4 & 9 & 23 & 16 \\
\hline Urban quintile 2 & 2 & 4 & 12 & 25 & 17 \\
\hline Urban other & 37 & 158 & 268 & 301 & 252 \\
\hline Total households & 710 & 807 & 440 & 702 & 643 \\
\hline
\end{tabular}


Using a variety of information sources, we have built an updated SAM for Pakistan that is perfectly consistent with the macroeconomic figures for the country and that is highly disaggregated, allowing for detailed distributional analysis of the economic structure of the country. ${ }^{7}$ The presented approach to building SAMs is motivated by an information theoretic approach to estimation (Judge and Mittelhammer 2012) that takes a Bayesian view of the efficient use of information: "Use all the information you have, but do not assume any information you do not have."

This SAM provides rich and updated detail on the income and expenditure patterns of the production sectors, production factors, and households of the Pakistani economy, reflecting in a significant way the heterogeneity of the income and expenditure compositions of domestic households and, as a result, allowing the distributional effects of changes in the composition of economic output to be traced. The SAM highlights a series of relevant characteristics of the Pakistani economy. The livestock (10.5\% of the economy) and trade (18.4\% of the economy) sectors are shown to be significant contributors to the total domestic value added. For agricultural products, land is, unsurprisingly, the largest component of value added. Manufacturing activities depend heavily on formal capital, while labor and other capital are important for most services. Large and medium farmers in Pakistan earn a large share of their income from land. However, small and landless farmers rely on labor, livestock, and other capital for most of their income. Rural nonfarm and urban households rely mostly on their labor and other capital as income sources.

The income multiplier analysis we subsequently conduct captures the production and consumption linkages in the economy. Taking into account the supply rigidities present in Pakistan, we use the semi-input-output model. Results suggest that the direct effects are larger than the indirect effects and that most of the indirect effects are concentrated in the services sector. ${ }^{8}$ The injection in the services sector has the lowest output multiplier for the entire economy. Finally, our analysis suggests that the injections lead to income changes that differ across socioeconomic groups, a direct result of the heterogeneity in the income generation of these groups that the countrywide database we estimated captures.

\section{Competing interests}

The authors declare that they have no competing interests.

\section{Appendix: Sectors in the Input-Output Matrix}

1 Crops: Rice (paddy)

2 Crops: Wheat

3 Crops: Cotton (seed cotton)

4 Crops: Sugarcane

\footnotetext{
${ }^{7}$ The resulting SAM is available at www.ifpri.org.

${ }^{8}$ The only exception is the injection in crops, with the largest indirect effect seen in industry.
} 
5 Crops: Tobacco

6 Crops: Other crops

7 Crops: Pulses and grams

8 Crops: Potatoes

9 Crops: Fruits

10 Crops: Vegetables and other condiments

11 Crops: Oil seeds

12 Crops: Other

13 Livestock

14 Forestry

15 Fisheries

16 Mining: Coal

17 Mining: Crude oil and natural gas

18 Mining: Other minerals

19 MF: Vegetable oils, etc.

20 MF: Milling

$21 \mathrm{MF}$ : Bakery products

22 MF: Sugar

$23 \mathrm{MF}$ : Other food products

24 MF: Beverages

25 MF: Cigarettes, tobacco

26 MF: Ginned cotton (lint)

27 MF: Cotton yarn

$28 \mathrm{MF}$ : Cotton cloth

29 MF: Art silk

30 MF: Made-up textile goods

31 MF: Knitwear

32 MF: Carpets

33 MF: Garments

34 MF: Other textile products

$35 \mathrm{MF}$ : Leather, leather products

36 MF: Footwear

37 MF: Wood, wooden products, furniture

38 MF: Paper, paper products

39 MF: Pharmaceutics

$40 \mathrm{MF}$ : Fertilizers and pesticides

41 MF: Chemicals: Consumer products

42 MF: Refined petroleum

$43 \mathrm{MF}$ : Rubber and plastic products

44 MF: Other chemicals

45 MF: Bricks, tiles

46 MF: Cement

47 MF: Other nonmetallic mineral products

48 MF: Basic metal products

$49 \mathrm{MF}$ : Other metal products

$50 \mathrm{MF}$ : Other nonelectrical machinery 
51 MF: Electrical equipment, etc.

52 MF: Other transport equipment

53 MF: Surgical instruments

54 MF: Handicrafts

55 MF: Sports goods

56 MF: Jewelry (precious metal)

57 MF: Other manufacturing products

58 Electricity and water works

59 Gas supply

60 Construction: Buildings and land improvement

61 Trade: Wholesale

62 Trade: Retail

63 Hotel and restaurant services

64 Transport: Railway

65 Transport: Road

66 Transport: Water

67 Transport: Air

68 Transport: Other and storage

69 Communication services

70 Banking: Central monetary authority

71 Banking: Other monetary institutions

72 Banking: Other credit institutions

73 Banking: Nominal product

74 Insurance

75 Real estate services

76 Imputed rent (owner-occupied dwellings)

77 Business services

78 Public administration and defense

79 Education

80 Healthcare

81 Other social and cultural services

82 Personal and household services

\section{References}

Agricultural Prices Commission (2003) Pakistan price statistics 2002-03. Agricultural Prices Commission, Islamabad, Pakistan

Agricultural Prices Commission (2009) Pakistan price statistics 2008-09. Agricultural Prices Commission, Islamabad, Pakistan

Debowicz D (2010) Modelling trade and financial liberalisation effects for Argentina. PhD thesis, University of Sussex, UK

Dorosh P, Niazi MK, Nazli H (2003) Distributional impacts of agricultural growth in Pakistan: a multiplier analysis. Pak Dev Rev 42(3):249-275

Dorosh P, Niazi MK, Nazli H (2004) A social accounting matrix for Pakistan, 2001-02: methodology and results. Pakistan Institute of Development Economics, Islamabad, Pakistan

FBR (Federal Board of Revenue) (2008) Pakistan customs tariff 2007-08. http://download1.fbr.gov.pk/ Docs/20101181511252278TarrifChapter1-972007-2008.pdf and http://download1.fbr.gov.pk/Docs/ 201011815112643390TarrifChapter98-992007-2008.pdf. Accessed February 15, 2012 
FBS (Federal Bureau of Statistics) (1991) Input-output matrix 1991. Federal Bureau of Statistics, Islamabad, Pakistan

FBS (Federal Bureau of Statistics) (1993) Social accounting matrix for 1984-85. Federal Bureau of Statistics, Islamabad, Pakistan

FBS (Federal Bureau of Statistics) (2001) Survey on community and personal services. Federal Bureau of Statistics, Islamabad, Pakistan

FBS (Federal Bureau of Statistics) (2002) Study on wholesale and retail trade, hotels and restaurants in Pakistan. Federal Bureau of Statistics, Islamabad, Pakistan

FBS (Federal Bureau of Statistics) (2004) National accounts of Pakistan: rebasing from 1980-81 to 19992000. Federal Bureau of Statistics, Islamabad, Pakistan

FBS (Federal Bureau of Statistics) (2006) Census of manufacturing industries 2005-06. Federal Bureau of Statistics, Islamabad, Pakistan

FBS (Federal Bureau of Statistics) (2008) Household Income and Expenditure Survey (HIES) 2007-08. Federal Bureau of Statistics, Islamabad, Pakistan

Golan A, Judge G, Miller D (1996) Maximum entropy econometrics: robust estimation with limited data. Wiley, New York

Golan A, Judge G, Robinson S (1994) Recovering information from incomplete or partial multisectoral economic data. Rev Econ Stat 76(3):541-549

Haggblade S, Hammer J, Hazell P (1991) Modeling agricultural growth multipliers. Am J Agric Econ 73(2):361-374

IMF (International Monetary Fund) (2010) Pakistan. IMF country report no. 10/158, IMF, Washington, $\mathrm{DC}$

Judge G, Mittelhammer R (2012) An information theoretic approach to econometrics. Cambridge University Press, Cambridge

Mellor JW (1995) Agriculture on the road to industrialization. Johns Hopkins University Press, Baltimore

Pakistan Institute of Development Economics (1985) A social accounting matrix of Pakistan for 1979-80. Pakistan Institute of Development Economics, Islamabad, Pakistan

Pakistan Institute of Development Economics (2001) Pakistan rural household survey 2001. Pakistan Institute of Development Economics, Islamabad, Pakistan

Pakistan, Ministry of Commerce (2011) Monthly statements showing exports and imports of select commodities 2010-11. http://www.commerce.gov.pk/trade-statistics. Accessed February 15, 2012

Pakistan, Ministry of Finance (2009) Economic survey 2008-09. Ministry of Finance, Islamabad, Pakistan

Pakistan, Ministry of Food and Agriculture (2009) Agricultural statistics of Pakistan 2008-09. Ministry of Food and Agriculture, Islamabad, Pakistan

Pal BD, Pohit S, Roy J (2012) Social accounting matrix for India. Econ Syst Res 24(1):77-99

PBS (Pakistan Bureau of Statistics) (2012) Gross national product of Pakistan (at current factor cost) 200708 data. http://pbs.gov.pk/sites/default/files/national_accounts/tables/table4.pdf. Accessed February 15,2012

Robinson S, Cattaneo A, El-Said M (2001) Updating and estimating a social accounting matrix using cross entropy methods. Econ Syst Res 13(1):47-64

Siddiqui R, Iqbal Z (1999) Social accounting matrix of Pakistan for 1989-90. Pakistan Institute of Development Economics, Islamabad, Pakistan

State Bank of Pakistan (2010) Handbook of statistics on Pakistan economy. State Bank of Pakistan, Karachi, Pakistan

UNCTAD (United Nations Conference on Trade and Development) (2008) Statistics. http://unctad.org/en/ Pages/Statistics.aspx. Accessed March 20, 2012

Waheed A, Ezaki M (2008) Aggregated and compact disaggregated financial social accounting matrices for Pakistan. J Econ Coop Among Islam Ctries 29(4):17-36

Zellner A (2004) Statistics, econometrics, and forecasting. Cambridge University Press, Cambridge 